\title{
KDO SO IZOBRAŽEVALCI, KI USPOSABLJAJO UČITELJE?
}

\section{POVZETEK}

Prvi del članka osvettjuje sodobno učenje učiteljev in spremembe v družbi, ki vplivajo na njihovo delo in posledično njihov profesionalni razvoj. Nato predstavi vlogo izobraževalcev pri učenju učiteljev in primere treh različnih profilov, ki pokrivajo to področje. Poudarek je na potrebnem znanju in kompetencah ter profesionalnem razvoju izob
nanizana odprta vprasanja in pobude, ki bi različna prizadevanja lahko povezali v skupen okvir.

Ključne besede: izobraževalci učiteljev, nadalinje izobraževanje in usposabljanje, ǔ̌enje, kompetence, profesionalni

\section{WHO ARE EDUCATORS THAT TRAIN TEACHERS? - ABSTRACT}

The first part of this paper highlights the view upon contemporary learning of teachers and changes in society which in-fluence their work and also their professional development. It proceeds by presenting the role of facilitators of competences and professional development. The paper concludes by setting some open questions and incentives to intertwine various indivi-dual endeavours into a common picture.

Keywords: facilitators of teachers, in-service teacher training, learning, competences, professional development

Na evropski konferenci ministrov za področje izobraževanja je dr. Pavel Zgaga (2010) poudaril, da so hitre spremembe v družbi povzročile tudi občutno spremembo vloge, ki jo ima izobraževanje. Poučevanje ne pomeni več zoolj usposabljanja za branje, pisanje in računanje. uzobraževanje in usposabjanje pihodnjh rodov učiteljev je treba pazljivo načrtovati, današnji pa morajo biti deležni močne podpore, da bodo lahko zadostili izzivom sodobnega časa. Kakšne učitelje torej potrebujemo danes in jutri? Poučevanje je poklic, ki mora biti sestavni del koncepta vseživljenjskega učenja: strokovni razvoj učiteljev mora poteka skozi celotno obdobje njihove kariere in biti podprt in spodbujan z usklajenimi podpornimi sistemi na nacionalni, regionalni in/ali lokalni ravni. Še več, od učiteljev se pričakuje, da sodelujejo $\mathrm{v}$ procesu, $\mathrm{v}$ katerem mladi in odrasli, ki se učijo, postajajo bolj opremljeni za avtonomno vseživljenjsko učenje.

V času hitrih sprememb, ki zahtevajo od človeka nenehno učenje, spreminjanje in ustvarjanje novega znanja, se spreminja tudi nacin, novega cčmo. Po eni strani se spreminja vsebina učenja, po drugi pa tudi sistemi in poti pridobivanja znanja in veščin. Formalno izobraževanje že dolgo ni več edini steber pridobivanja znanja in veščin. Načela vseživljenjskega učenja, ki so odgovor na spremenjene razmere, tako odpirajo vrata tudi tacitnemu/skritemu znanju. Od vsakega posameznika, institucije in družbe nasploh se pričckuje stalno in sprotno učenie iz nairazličnejših virov in po mnogih poteh. Sprenenen pogoji življenja in učenja zato zahtevajo tudi iskanje raznolikih metod in oblik učenja. Poklic učitelja pa se kljub številnim reformam, zunanjim spremembam in izzivom, ki jih prinašajo socialne in ekonomske okoliščine te odkritja znanosti, ne spreminja in prilagaja dovolj hitro. Učiteljeva profesionalnost postaj pomemben pogoj za uspešno spopadanje s spremenjenimi okoliščinami, saj je lahko uspešen le učitelj, »ki je zmožen poglobljene in situaciji primerne strokovne presoje (refleksije) ter obvladovanja širokega repertoarja metod in pristopov« (Požarnik, 2000: 33). Strokovni razvoj učiteljev je bistven za zagotavljanje razvoja in ohranjanje inovativne prakse.

V izobraževanju, usposabljanju in učenju učiteljev imajo pomembno vlogo izobraževalci (učitelji) učiteljev, ki jih v fazi dodiplomskega, podiplomskega ali nadaljnjega izobraževanja in usposabljanja pri učenju podpirajo, usmerjajo, jim pomagajo in jih vodijo. $\mathrm{V}$ članku bomo izhajali iz specifike učenja učiteljev in se dotaknili vprašanj, kdo so izobraževalci učiteljev, od kod prihajajo in kaj naredijo za njihov profesionalni razvoj.

\section{ZNAČILNOSTII SODOBNEGA} UČENIA UČITELJEV

V sodobni družbi znanja se morajo ljudje naučiti učiti se, saj bodo verjetno v šolah predmet sami postali manj pomembni od sposobnosti in motivacije za nenehno učenje (Drucker po Sachs, 2003). Učitelji in šole morajo stopiti korak naprej po poti partnerstva z učenci, stars, rak lokalni skup postmi, podjeji in postat sestayni del od tega siseme pombno, ali se učenje dogaja v šoli ali zunaj nje, dobri učitelji, ki imajo potrebno znanje o učenju in učencih, bodo vedno potrebni. Spreminja pa se njihova vloga, saj se iz posredovalcev znanja spreminjajo v svetovalce za učenje. Meje med učiteljem in učencem so pogosto zabrisane, sa v procesu učenja odgovori niso več ključnega pomena. Ključna postajajo vprašanja.

Hargreaves in Fullan (2000) trdita, da se z razvojem znanosti o poučevanju kot npr. uvajanjem konstruktivizma, sodelovalnega učenja, uporabe tehnologij, prilagajanjem poučevanja učnim stilom in potrebam učencev iz različnih okolij in integracijo

otrok s posebnimi potrebami širi tudi obseg učteljevega dela in spreminja njegova vloga. Finska strokovnjaka (Hirvi, K. Niinisto, 1996) med novimi vlogami učitelja poudarjata predvsem odprtost za spreminjanje, kajti učitelj izgublja nekatere tradicionalne vloge (npr. skoraj edini vir informacij), jih prilagaja novim okoliščinam (mentorska vloga, organizacija učnih situacij, intenzivnejše vključevaje učencev ...) in sprejema nek re nove vloge (vkljucer. re pouk). Opazna je tuci veja potreba po mobilnosti učiteljev. Današnjega učitelja vidita predvsem kot iniciatorja sprememb (»change agent«), poleg te pa v ospredje postavljata še naslednje vloge: učitelj kot spodbujevalec učenja, učitelj, ki skrbi za svoj osebni in profesionalni razvoj, učitelj, ki je del razvijajoče (učeče) se organizacije. Naloga današnjega učitelja je biti iniciator sprememb (»change agent $\ll$ ).

Peter Vaill (1996) je uporabil metaforo o deročih vodah, da bi opisal kompleksno in spreminjajoče se okolje, v katerem živimo. Zanj je značilna nepričakovanost, neobičajnost, prepletenost, nepredvidljivost in velika poraba virov. Ti kompleksni, medsebojno odvisni in nestabilni sistemi, ki sestavljajo naše življenje, zahtevajo nenehne izvirne, ustvarjalne pobude in odzive. Njegova teza je, da je prav ta aktivnost tisto, kar imenujemo trajno učenje. Č parafraziramo: »Trajno učenje je tisto, kar vidimo, če opazujemo ravnanje ljudi v kompleksnih situacijah.«(Vaill, 1996: 35.)
Naloga današnjega učitelja je biti iniciator sprememb (»change agent ). 
Prav tako kot je za učence razred zgolj eno od kolij za učenje, morajo učitelju možnosti, ki jih daje strokovni razvoj, zagotoviti različn učne izkušnje, ki ga spodbujajo, da raziskuje in razmišlja o svoji praksi in pogledih. Učitelji morajo v prvi vrsti sami postati učenci, ki se učijo od zibelke do groba, kar je tudi eden ključnih elementov odprtega profesionalizma učiteljev. Po Sachsu (2003) novi profesionalizem učiteljev zahteva drugačen okvir razmišljanja in mobilizacijo njihovih sil. Temelje proaktivnega in odgovornega pristopa k profesionalizmu sestavlja pet elementov: učenje, participacija, kolaboracija, kooperacija in aktivizem. Drucker, ki učitelje imenuje delavce znanja v družbi znanja, trdi, da je treba v profesionalnem razvoju učiteljev doseči premik: od upravičenosti za........k odgovornosti za in od spodbujanja za........k prispevanju za.

\section{ZNAČILNOSTI UČENIA}

\section{ODRASLIH}

Glavno sporočilo o učenju odraslih je, da je za svoje učenje odgovoren posameznik in da je odgovornost učitelja odraslih vodenje odraslega skozi proces učenja. Lahko bi torej rekli, da se počasi izgublja tradicionalna vloga učitelja, ki nadzoruje proces in vsebino učenja tako, da opredeli situacijo in postopke ter določi, kaj je prav in kaj narobe. Prav ta spremenjena paradigma je temelj, na katerem i jicer opredeli proces, v kateren bo uč pok potekalo, toda ne razsoja o tem, kaj je prav ali ustrezno v nekem primeru. Udeležence spodbuja, da uporabijo svojo lastno presojo in sposobnosti sprejemanja odločitev.

Knowles (1990) opredeljuje pet temeljnih predpostavk o učenju odraslih:

Majvečji meri izvira iz njihovih lastnih potreb in interesov, kar pomeni, da je na začetku procesa učenja treba graditi na teh temeljih.

2.Odrasli so usmerjeni v učenje o temah, ki se dotikajo njihovega življenjskega ali delovnega okolja. Primeren okvir so torej praktične situacije iz njihovega življenja in ne akademsko zastavljene teoretične vsebine.

3.Izkušnje so najbogatejši vir učenja odraslih. Bistvo učenja mora biti zajeto $\mathrm{v}$ aktivnem, načrtnem sodelovanju povezanih izkušenj, analizi teh izkušenj in njihovi aplikaciji na delovne in življenjske situacije.

4. Odrasli imajo močno razvito potrebo po samousmerjanju, zato je vloga moderatorja/učitelja odraslih predvsem vključevanje udeležencev v raziskovanje, analiziranje in vodenje $\mathrm{v}$ procesu pridobivanja novih znanj in spretnosti.

5. Individualne razlike med posamezniki se $\mathrm{z}$ leti in izkušnjami povečujejo. Zato se mora usposabljanje odraslih prilagajati razlikam v stilu, času, prostoru in tempu učenja odraslih.

Teorija na področju HRM je poskušala odgovoriti na vprašanje, kaj lahko pomaga ljudem pri učenju. Warries in Peters (1992 po van Lakerveld, 2006) sta razvila uporaben model, ki ga sestavlja pet determinant uspešnega učenja odraslih. ARCS je akronim (»attention, relevance, confidence, satisfaction $\ll)$, ki zajema pozornost - pridobiti moramo pozornost udeležencev; pomembnost - prepričati jih moramo, da je to prava vsebina za njih; zaupanje - zastavljeni cilji morajo biti udeležencem dosegljivi; in zadovoljstvo - učenje mora zadovoljiti njihovo potrebo. Pri tem pa je treba je treba pedno neposredno zadovoljitrijo potrebe in dolgoročnimi rezultati učenja. Pogosto je prijetna učna izkušnja hitro pozabljena, tista, ki je zahtevala dolgotrajen in včasih težaven proces prehajanja na višjo raven, pa ima lahko dolgotrajne učinke. Zanimivo je, da so se v raziskavi Zavoda RS za šolstvo (Mršnik et al, 2005) učiteli med različn oblik Jîn odločali za krajše oblike (eno- ali dvodnevne seminarje), ki so prinašale takojšen, vendar kratkoročen učinek, kot za celoletne projekte, ki so jih sami umestili najviše, kar se tiče dol-
Po pregledu obsežne literature so strokovnjaki (ur.: Swennen, van der Klink, 2010) opredelili značilnos uspešnega učenja odraslih. Učenje naj bo:

aktivno (Gollob, Huddleston, Krapf, Salema \& Spajic-Vrkas, 2005),

.konstruktivno - razvijamo in oblikujemo lastno zn nje in kompetence (Kessels, van Lakerveld \& van de Berg, 1998),

3.socialno - učenje $\mathrm{z}$ drugimi in od drugih Fenwick\&Tennant, 2004),

4. samousmerjano - učenec je upravljavec svojega učnega procesa (Fenwick\&Tennant, 2004),

5. refleksivno - vključuje proces refleksije posameznikovega delovanja in tudi samega procesa učenja (Gollob et al., 2005)
Slika 1: Področja in pogoji učenja učitelia

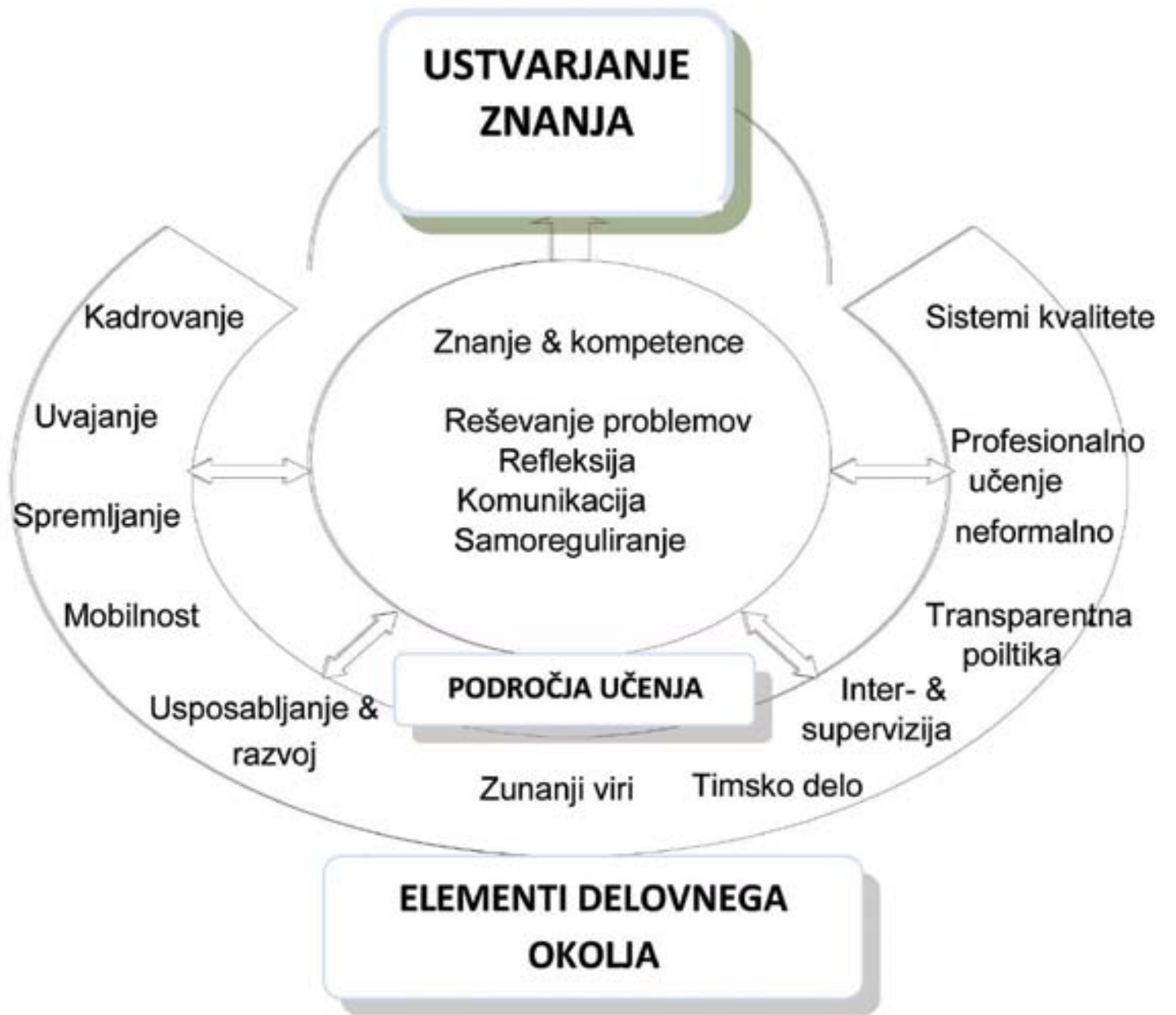


goročnih učinkov na vzgojno-izobraževaln delo, so pa od njih terjali mukotrpno delo.

Zavedati se moramo, da se odrasli učijo v azmerah, ki so delno organizacijske in jim omogočajo učenje iz različnih virov, npr. seminarji, kolegialni pogovori, svetovanje, supervizija, refleksija, samoevalvacija, sodelovanje z zunanjimi strokovnjaki, mreže. Vse to sestavlja profesionalno učenje. $\mathrm{V}$ projektu CLIMATE (2010) smo raziskovali področja učenja, na katera se po Kesselsu (1996) organizacija osredotoča, da bi izboljšala svoje znanje. To so znanje in kompetence predmetnega področja, reševanje problemov, refleksivne veščine in metakognicija, komunikacijske veščine ter samoregulacija motivacije in čustev. Elementi, ki v delovnem okolju učitelja spodbujajo in podpirajo učenje, so naslednji :

- kadrovanje in uvajanje - jasnost glede znanja in spretnosti, ki so potrebni za opravljanje poklica

- ocenjevanje, spremljanje - povratna informacija glede opravljanja poklica;

- mobilnost - prehajanje med različnim vlogami, situacijami, okolji;

- usposabljanje - nadaljnje izobraževanje in usposabljanje učiteljev,

- sodelovanje - kolegialno učenje z drugim in od drugih;

- supervizija in intervizija - osredotočeno učenje

zagotavljanje kakovosti - povratna informacija o uspešnosti in učinkovitosti učiteljevega delovanja;

- zunanje povezovanje - partnerstva z drugimi šolami in inštitucijami zunaj šolskega prostora;

- samoregulirano učenje - ozaveščanje in umeščanje učenja kot načrtna aktivnost skupine.

Področja učenja v povezavi s pogoji, ki so potrebni za učenje, lahko spremenijo delovno okolje v učno okolje (Slika 1).
Novi koncept nadaljnjega izobraževanja in učenja ter kompleksnost okolja zahtevata tudi nenehno profesionalno vseživljenjsko učenje izobraževalcev učiteljev, ki bodo moeni strani nenehno izpostavjetremislekom in na drugi strani podpori pri svojem profesionalnem učenju in razvoju. Začeti bodo morali komunicirati med seboj, izmenjevati znanje, skupaj razmišljati o razvoju družbe kot celote in posebej o področju izobraževanja in učenja. Šele ta(a) učenja (Lunnenberg, Korthagen in Swennen, 2007 v ur. Swennen, van der Klink, 2010).

\section{VLOGA IZOBRAŽEVALCEV V}

\section{UČENJU UČITELJEV}

Učenje učiteljev se je spremenilo, saj se je od poudarka na vsebini in učnih rezultatih usmerilo $\mathrm{k}$ spodbujanju učnega procesa in sposobnosti za učenje. Sprenemba v pogledu na učenje učiteljev se kaže tudi v težnji po spremembi imena, i označuje organizirano učenje $v$ času učiteljeve karierne poti. Nadaljnje izobraževanje in usposabljanje se spreminja $\mathrm{v}$ nadaljnje učenje (»inservice training - inservice learning «). Na evropski ravni se v okviru Evropskega združenja za izobraževanje učiteljev (ATEE) s področjem izobraževanja in usposabljania učiteljev ukvarja zup skupina strokovnjakov, ki se projektno povezuje in spremlja trende razvoja učenja učiteljev (www. atee1.org). V zadnjih 20 letih svojega delovanja se je $\mathrm{v}$ svojih publikacijah dotaknila koncepta nadaljnjega izobraževanja in usposabljanja, načina izobraževanja izobraževalcev, pripravništva, mentorstva, ustvarjanja ugodnega okolja za učenje, torej vseh ključnih elementov ključnih elementov na učiteljevi poti učenja.

Skladno s spremembami se mora na novo opredeliti tudi vloga strokovnjakov, ki podpirajo razvoj učiteljev in šol. V slovenskem jeziku še nismo našli ustreznega izraza, ki bi povzel vso dinamiko in kompleksnost, ki jo obsega ta vloga. Ime odraža tradicionalen način razmišljanja o procesu učenja in poučevanja. A prav tako kot se je spremenila vlog a učitelja, se spreminja tudi vloga izobraževalca učiteljev. Slednji vse bolj postaja spodbujevalec, olajševalec, pospeševalec, usmerjevalec, podpornik učenja (ৈfacilitator). V prispevku bom prispevku bom zaradi jasnosti ohranila izraz izobraževalec, vendar ga razumem $\mathrm{z}$ vidika bogastva celotne palete pomenov, ki jo obsega angleška beseda »facilitator

Vloga izobraževalca vključuje pripravo, načrtovanje, razvoj, izvajanje in evalvacijo nadaljnjega izobraževanja in usposabljanja ter obsega različna zaporedja, dinamiko in vzorce. Izobraževalec mora znati oceniti potrebe in pričakovanja udeležencev. Poseben problem se pojavi, če se potrebe udeležencev in pričakovanja vodstva šole ne ujemajo. V tem primeru je naloga izobraževalca usklajevanje, pogajanje, dogovarjanje, redefiniranje. Postavlja se vprašanje, kdo je v resnici v tem primeru stranka. Ce se učitelji odločajo za

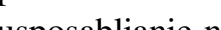
usposabjanje na podlagi lastnih potreb, bodo drugače gledali na izobraževalca, kot če jim je ta potreba vsiljena. Če udeleženci ne čutijo, da bi bile aktivnosti za njih koristne, učni proces le redko obrodi sadove in ni težaven le za izobraževalca, temveč je lahko celo neuspešen (Lendahl Rosendahl \& Ronnerman, 2006 v ur.: Swennen, van der Klink, 2010).

Vloge izobraževalcev $\mathrm{v}$ procesu spodbujanja učenja učiteljev in podpiranja šol so zelo raznolike. Na seminarjih usposabljajo za določene predmete ali teme, vse bolj pa je njihova vloga usmerjena $\mathrm{v}$ podporne aktivnosti, kot sta mentorstvo in coaching. Učenje lahko podpirajo $\mathrm{z}$ ustvarjanjem primernega učnega oloja, apr s pojočjo informa nikacijse tehnogjo. Lahko prevzmunikacijske tehnologje. Lahko prevzamejo vlogo v okviru aktivnosti znotraj organizacije, kot so ocenjevalni intervju, strokovn srečanja, medkolegialne konzultacije, samoe- valvacija, refleksija itd (van Lakerveld 2005 v ur.: Swennen, van der Klink, 2010). V zadnjem času se vse pogosteje omenja vloga raziskovalnih aktivnosti pri pridobivanju novih vpogledov in razumevanja za izboljševanje učiteljeve prakse. Akcijsko raziskovanje se je pokazalo kot zelo uspešna metoda podpore profesionalnega razvoja učiteljev (Mršnik et al., 2005).

\section{KDO SO IZOBRAŽEVALC}

\section{UCITELJEV}

Sestava predavateljev $\mathrm{v}$ okviru programov nadaljnjega izobraževanja in usposabljanja, ki jih izvaja Zavod RS za šolstvo, je tripartitna: svetovalci, visokošolski predavatelji/teoretiki in učitelji praktiki. Pri oblikovanju take zasedbe smo upoštevali spoznanja o učenju učiteljev, saj je vsaka profesionalna odločitev in njena iz vedba rezultat prepletanja vseh treh dejavnikov: poznavanja »znanstvenih « konceptov, osebne teorije in $\mathrm{z}$ izkušnjami pridobljenih praktičnih modelov razumevanja in ravnanja (Požarnik, 2000). Zato mora tudi usposabljanje učiteljev vključevati vse tri dimenzije, saj drugače lahko učitelj nekaj ve o poučevanju, vendar tega ne zna udejanjiti v praksi ali pa svojih odločitev ne zna prilagajati različnim kontekstom in se togo drži »predpisanih postopkov«. Povezovanje vseh treh vidikov $\mathrm{v}$ enotno celoto, ki ji pravimo profesionalno razmišljanje in delovanje, ter njeno nadgrajevanje in šin cilji vseživljenjskega strokovnega razvoja učiteljev.

Kako postati izobraževalec, kakšne so poti v karieri, ali je za to potrebna licenca? Ce pogledamo trenutno sliko, vidimo, da so njihova izobrazba, kariera in predznanje zelo raznoliki. Nekateri so izkušeni učitelji, drugi svetovalci, coachi, raziskovalci, supervizorij.. $\mathrm{V}$ nadaljevanju bom predsavila ti različne profile izobry̌evalcev učiteljev: svetovalca Zavoda RS za šolstro, učitelja palsva ina Zavoda RS za šolstvo, ga področja 
KOMPETENCE

SVETOVALCEV
Globalni subjektivni občutek, pričakovanje ali prepričanje posameznika, da je sposoben uresničiti in doseči rezultate (učinke, cilie), h katerim je usmerjen ali se od njega pričakujejorkliučujejo

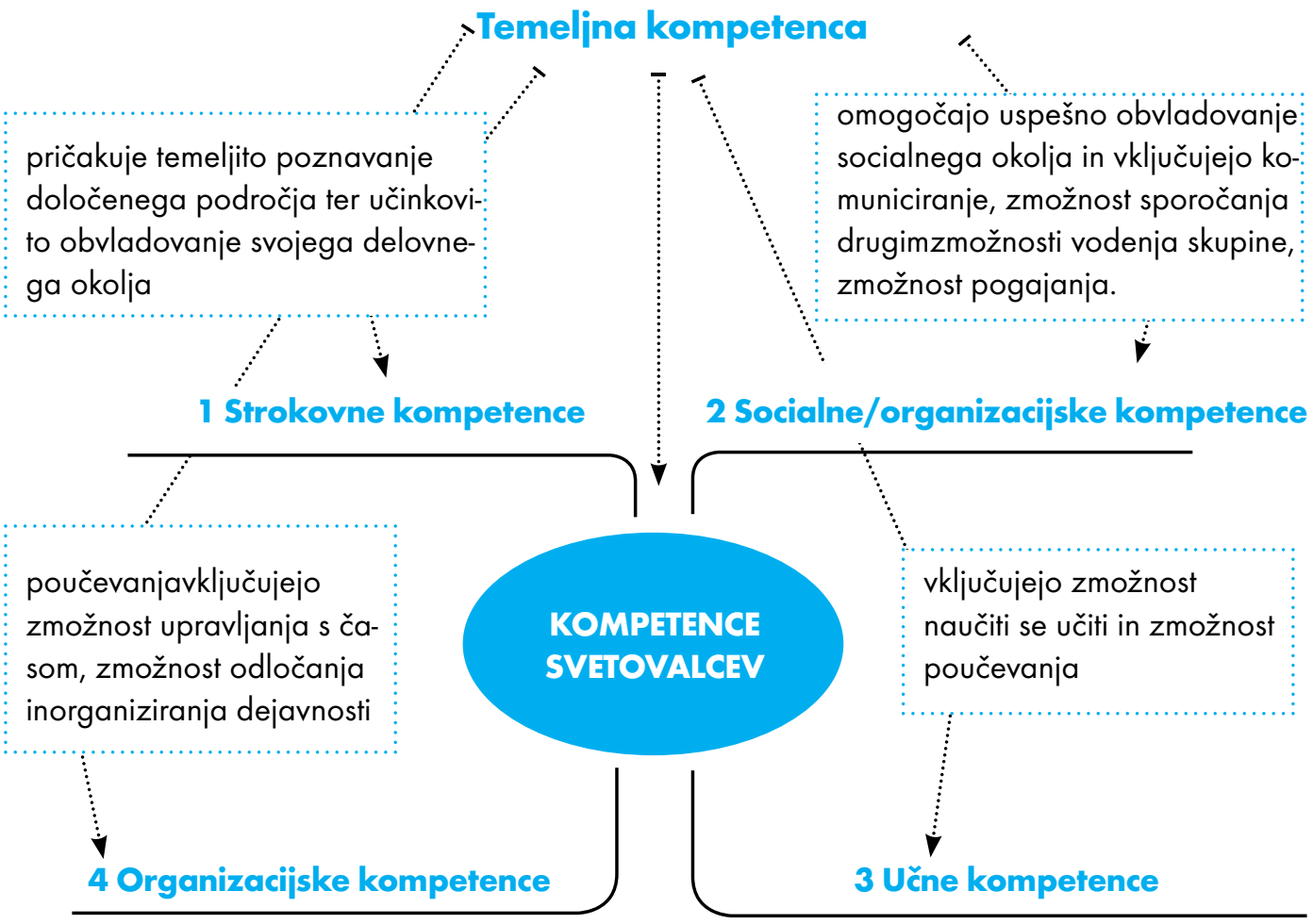

\section{SVETOVALCI V VLOG}

\section{ZOBRAŽEVALCEV UČITELJEV}

Zavod RS za šolstvo kot svetovalce zaposluje strokovne delavce $\mathrm{z}$ izkušnjami $\mathrm{v}$ neposrednem pedagoškem delu. Uspešnost na tem področju je temeljni pogoj, ki zagotavlja, da bo svetovalec kos nalogam, ki jih mora opravljati Zavod RS za šolstvo. To pa še zdaleč ni dovolj. Za načrtovanje in spodbujanje razvoja pedagoške prakse, ki je glavna naloga Zavoda RS za šolstvo, vsak svetovalec potrebuje še vrsto drugih praktičnih in teo- retičnih znanj, ki jih kot učitelji niso potrebovali in jih zato tudi kot svetovalci nimajo. Hrvaški kolegi (Milović, 2010) so opredelili vloge svetovalca, ki se med seboj prekrivajo in prepletajo. Svetovalec naj bo s svojim vedenjem in ravnanjem vzor, biti mora dober organizator, motivator, opazovalec, polušalec, pom̌n slušalec, pomočnik, prenašalec informacij, reševalec konfliktov, entuziast, načrtovalec, učitelj spretnosti, poznavalec stroke. Vse to pa zahteva trajen profesionalni razvoj, refleksijo in samovrednotenje izkušenj, kar je po- goj za osebno in profesionalno rast vsakega posameznika.

$\mathrm{V}$ okviru projekta Strokovna in osebnostna ras (Žarkovič et al., 2004) smo na podlagi opredeljenih kompetenc svetovalca izdelali vprašalnik, $\mathrm{k}$ je podlaga za načrtovanje profesionalnega razvoja zaposlenih, lahko pa služi tudi kot izhodišč za oblikovanje profila svetovalca in za pripravo programa izobraževanja.

Opredelili smo štiri sklope kompetenc, ki skupa tvorijo temeljno kompetentnost, ki je globaln subjektivni občutek, pričakovanje ali prepričanje posameznika, da je sposoben doseči rezultate (učinke, cilje), h katerim je usmerjen ali jih od njega pričakuj petence, socialne/komunikacijske kompetence, učne kompetence in organizacijske kompetence. Kompetentnost pedagoških svetovalcev smo opredelili na dveh ravneh: na ravni pristojnosti in na ravni strokovnosti. Pri opredelitvi pristojnosti pedagoškega svetovalca smo izhajali iz temeljnih nalog Zavoda RS za šolstvo. Zato smo najprej določili temeljna področja delovanja zavoda, v okviru katih deluje pedagoši svetovalec. Temeljna področja delovanja zavoda so: oblikovanje novih pedagoških rešitev (načrtovanje), uvajanje novosti in sprememb ter spremljanje dogajanja $\mathrm{v}$ šolskem prostoru. Vsa tri področja sestavljajo razvojni krog in jih povezuje proces prenašanja posebnih znanj in izkušenj na druge.
Druga raven so strokovne kompetence. Strokovno kompetentnost lahko opredelimo kot lastnost strokovnjaka, ki temeljito pozna neko področje in učinkovito obvladuje svoje delovno okolje. Strokovno kompetentnost sestavljata poznavanje nekega področja in obvladovanje svojega delovnega okolja. Opredelitev vključuje dva vidika: temeljito poznavanje nekega področja in obvladovanje delovnega okolja. S poznavanjem nekega podroçja mislimo na znanja, ki jih strokovnjak ima oziroma jih je pridobil $\mathrm{v}$ času formalne-

Strokorno kompetentnost sestanekega področja in obvladovanje svojega delovnega okolja. anja mu omogočajo izvajanje delovnih nalog. Posameznik je za izvajanje del in nalog na tem področju usposobljen in poklican. Usposobljenost dokazuje $\mathrm{z}$ uradnim listinami (diploma, specializacija ...). Hkrati je to tudi dokaz, da nekdo lahko opravlja poklic oziroma delovne nloge, kot so opredeljene v zaciji. Sklop delovnih kompetenc se veže na temeljito poznavanje predmetnega področja in stroke; preostali sklopi kompetenc pa so povezani $\mathrm{z}$ obvladovanjem delovneg okolja. Tako opredeljene kompetence zahtevajo dinamičen in odprt model strokovnega in osebnostnega razvoja svetovalca, ki vključuje vljata poznavanje

Kandidati so v procesu usposabljanja razvijali vsebinska znanja, ki so obsegala poglobljeno strokovno znanje na izbranem področju in poznavanje značilnosti učenja odraslih. Veščine, ki so jih razvijali, pa so bile dobra komunikacija: poslušanje, povzemanje, zastavljanje vprašanj, dajanje povratne informacije, usmerjanje $\mathrm{h}$ konsenzu, aktivno sodelovanje, prispevanje $\mathrm{k}$ skupnim ciljem, povratne informacije, usmerjanje $\mathrm{h}$ konsenzu, aktivno sodelovanje, prispevanje k skupnim ciljem,
kulturni dialog (ekonomičnost in jasnost izražanja, uvidevnost, učinkovitost), organizacija časa, kulturni dialog (ekonomičnost in jasnost izražanja, uvidevnost, učinkovitost), organizacija časa,
prostora, dejavnosti in pripomočkov, delo z odraslimi (motiviranje, komunikacija), spodbujanje in usmerjanje drugih v samoizobraževanje ter strokovni razvoj in uporaba IKT pri pripravi ter izvajanju izobraževanja. Naravnanosti (odnos in navade), ki smo jih spodbujali, so bile strpnost do posameznikov $\mathrm{v}$ skupini in upoštevanje različnih mnenj in stališč, prispevanje in usmerjanje $\mathrm{k}$ pozitivni klimi ter reflektiven odnos do lastnega dela in dela drugih (Žarkovič, 2006). 
ja odprto vprašanje, kako osvojene kompetence formalizirati v okviru zavoda ali širše.

\section{UČITELII PRAKTIKI V VLOGI}

IZOBRAŽEVALCEV UČITELJEV

S projektom Izobraževanje izobraževalcev smo v letih 2004 do 2006 v okviru sredstev Evropskih strukturnih skladov želeli na Zavodu RS za šolstvo povečati možnosti za širjenje aktualnega znanja med učitelji ter pripomoči k njihovemu profesionalnemu razvoju z ustvarjanjem ugodnih pogojev za učenje. Vodila so nas načela razširjenega profesionalizma, saj smo usposabljanje zastavili kot povezavo teorije in prakse, $\mathrm{v}$ središču je bilo sodelovanje med učitelik, $z$ aktivnostmi je žcli pa smo želeli spoch ju jü druge strokovne dejavnosti, jih navdušiti za strokovno literaturo, teoretična spoznanja in vključevanje $\mathrm{v}$ širši socialni kontekst izobraževanja Ekspertne skupine so pripravile ustrezne programe in usposobile potrebno število izobraževalcev multiplikatorjev. Ti učitelji so svoje znanje dodatno izobraževali in usposabljali.

sodelovanju smo povabili strokovne delavce, ki so bili pripravljeni postati izobraževalci učteljev ter si z dodatnim izobraževanjem in usposabljanjem pridobiti naziv multiplikator Zavoda RS za šolstvo. V razpisu za prijavo kandidatov smo navedli pogoje, med drugim visokokakovostno opravljanje poklicne dejavnosti $\mathrm{v}$ dosedanjem delu, prednost pri izbiri so imeli kandidat s specializirano bazo znanja določene teme in dokončano univerzitetno izobrazbo. Ob koncu usposabljanja so pridobili dovoljenje za opravljanje dela, pri tem so morali izkazovati avtonomijo pri opravljanju dejavnosti in prevzemanju odgovornosti (opredeljeno v pogodbi o sodelovaju), lelovi so morli ska clovati so morali sklactiko (predavanje za Zavod RS za solstro). Kot temeljni pogoj je bilo treba med drugim dokazati tudi zmožnost komuniciranja $\mathrm{v}$ strokovnem jeziku. Pogoji na razpisu in zahteve, zapisane v pogodb so značilnosti profesionalcev, kot jih opredeljuje Požarnik (2000, 34, po Bauer, 1999, Hargreaves, 2000, Marentič Požarnik, 1996, Razdevšek Pučko 1997 idr.).

$\mathrm{V}$ projektu je bil cilj delovati na ravni kolegialnega profesionalizma (Hargreaves, 2000), elementov sodeloalne kulture med učitelji (razvijanje veščin aktivnega sodelovanja in prispevanja $\mathrm{k}$ skupnim ciljem), v spodbujanju učiteljeve samozavesti in avtonomije ob uporabi sodobnih pristopov timskega dela ter $\mathrm{v}$ spodbujanju reflektivnega odnosa in uvajanju samoevalvacije s pomočjo portfelja.

\section{VISOKOŠOLSKI PREDAVATELJI V VLOGI IZOBRAŽEVALCEV}

\section{UČITELIEV}

Visokošolski predavatelji s fakultet so ključni nosilci znanja, ki so ga učitelji kot študenti pridobili med študijem. Večinoma tudi sami izhajajo iz učiteljskih vrst in so svoje akademsko znanje osredotočili na specifično strokovno področje. Posebnih andragoških znanj med podiplomskim študijem običajno ne pridobijo. Z izobraževanjem odraslih se srečujejo $v$ sistemu nadaljnjega izobraževanja in usposabljanja, kjer učitelji nadgrajujejo svoje znanje in se seznanjajo z novostmi $\mathrm{v}$ stroki. Med udeleženci $\mathrm{v}$ dodiplomskem izobraževanju in tistimi v nadaljnjem izobraževanju in usposabljanju pa obstaja pomembna razlika.

Bulskool in drugi (2010) navajajo sedem posebnih področij, ki so bolj specifična za učenje odraslih v primerjavami s kompetencami, potrebnimi v okviru dodiplomskega izobraževanja. Navajajo ekspertizo in izkušnje udeležencev, ki jh ti prinašjo v učni proces in so v fukciiji obogatenega učnega okolja. Didaktičn kometence, ki so specifičn za delo z odraslin injo za delo z odraslimi, imajo nju. Sledi kompetenca opolnomočenja odraslih $\mathrm{v}$ procesu učenja, kjer $\mathrm{z}$ vključevanjem prejšnjih izkušenj udeleženci sooblikujejo učni proces. Raznolikost v skupinah odraslih je povezana z izkušnjami, ki jih je treba znati oceniti in na njihovi podlagi zgraditi ustrezne učne strategije. Spodbujanje in podpiranje učnega procesa sta $\mathrm{v}$ funkciji na učenca usmerjenega pristopa, ki ga

dodatno nadgrajujeta svetovanje in usmerjanje. $\checkmark$ slovensken prostor sta se $z$ vprašanjem kompetenc, ki jih potrebujejo izobraževalci odraslih, ukvarjali dr. Marentič Požarnik in dr. Cencič. Cencič (2010: 40) pravi: »/.../ da se maloštevilne dosedanje raziskave posvečajo tistim izobraževalcem učiteljev, ki delujejo $\mathrm{v}$ univerzitetnem okolju in so vanj prešl kot učitelji iz osnovnih in srednith šol. Gre predvsem za učitelje specialnih didaktik pa tudi splošnih pedagoških predmetov. Prehod $\mathrm{v}$ 'akademsko' okolje in sprememba poklic ne identitete ni preprost; ponekod skušajo novincem prehod olajšati s povezovanjem v kolegialne študijske skupine 'communities of practice' (Nizozemska, Izrael, Anglija ...), z oblikovanjem seznamov kompetenc oziroma standa in s posezovajem v strokoma združenja, kot je VELON na Nizozemskem (Murray in Harrison, 2008: 110-114 v Cencič 2010).《

Navaja, da je pri nas raziskava, usmerjena na vprašanje, kateri dejavniki vplivajo na profesionalno identiteto in razvoj izobraževalcev učiteljev, opravljent učiteljev, opravje in podlagi globinski polstrukturiranih intervjujev, pokazala, da je na njihov razvoj razmeroma malo vplival (pretežno teoretsko usmerjen) študij, pač pa prve izkušnje s poučevanjem, tudi negativne, če so jih dobro predelali, podpora kolegov, stiki v mednarodnem prostoru (Marentič Požarnik, Valenčič Zuljan, 2001 v Cencič, 2010).

\section{RAZMISLEK IN ODPRTA}

\section{VPRASANIA}

Cencič (2010) ugotavlja, da so izobraževalc učiteljev osrednja skupina strokovnjakov, od katere je odvisna kakovost izobraževanja in usposabljanja učiteljev. Vendar je o tej skupini strokovnjakov še vedno znano bolj malo. Gre za zanemarjeno področje proučevanja, kot je ugotovila že Kari Smith (2003). V zadnjih petih letih se povečuje število raziskav o uvajanju in profesionalnem razvoju izobraževalcev učteljev (European Journal of Teacher Education 2008), še vedno pa ni dovolj empiričnih izsledkov o njihovem profesionalnem razvoju.

Programski svet za nadaljnje izobraževanje in usposabljanje $v$ okviru ministrstva za šolstvo in šport je oblikoval kriterije evalvacije predlogov programov nadalinjega izobrǎ̌evanja in uspo-

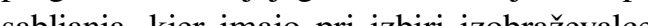
pomemb vo spevkov, sodelovanje $\mathrm{v}$ projektih in praktične izkušnje $\mathrm{v}$ dosedanjem izobraževanju, zlast tiste $\mathrm{z}$ neposrednim pedagoškim delom na izbranem področju. $V$ tem naboru je zajetih več dejavnikov njihove profesionalnosti, a potrebne bi bile bolj poglobliene raziskave, ki bi osvetlile dejavnike profesionalnega razvoja izobraževalcev učiteljev.

Pri izobraževanju odraslih pomembno vlogo opravlja Andragoški center Slovenije, ki strokovni javnosti omogoča spremljanje razvojnih trendov in izsledkov s tega področja. Objavljen so številna poročila raziskave in prispevki s konferenc, kjer avtorii predstavliajo svoje poglecte in spoznanja v zvezi $z$ vlogo in kompetencam izobraževaca odra icte identiteto in nadaljnjim profesionalnim razvojem. Leta 2004 je Nives Ličen na Andragoškem kolokviju predstavila profesionalne kompetence, ki jih potrebuje ekspert na področju vzgoje in izobraževanja odraslih, ter jih opredelila kot: vsebinske, didaktične, področne/kontekstualn in procesne kompetence.

$\checkmark$ okviru študije Kompetenčni pristop k izobraževanju andragoških delavcev, ACS 2009, je So- 
nja Klemenčič navedla ugotovitve razprav fokusih skupin, kjer so opredelili lastnosti dobrega zobraževalca. To so bile: je empatičen, komunkativen, motivator, se prilagaja potrebam udeležencev, je strpen in prijazen, dobro upravlja čas, je strokoven, kritičen, suveren in avtonomen pri svojem delu, sposoben timskega dela in osebnostno zrel. Kompetence in znanje, ki si jih morajo pridobiti izobraževalci odraslih, zajemajo ugotavljanje izobraževalnih potreb, načrtovanje in prilagajanje učnega procesa skupini in posamezniku, spremljanje in vrednotenje lastnega dela, sodelovanje v skupini, povezovanje $\mathrm{z}$ okoljem ter pripravo učnih gradiv in vodenje udeleženca skozi proces učenja.

Zeleni knjigi (2001) je bilo pred slabimi desetimi leti zapisano, da sta kakovost in uspešnost zobraževanja učiteljev odvisni od usposobljenosti in strokovnosti izobraževalcev učiteljev in da so bila dosedanja prizadevanja za profesionalizacijo njihove dejavnosti skromna. Treba bi bilo razviti in izoblikovati zelo jasne opise profilov izobraževalcev učiteljev. Kvalifikacije, ki jih imajo izvajalci, so v primerjavi z drugimi področji strokovnega izobraževanja preskromne. Večje zahteve glede formalnih kvalifikacij izobraževalcev učiteljev ter ustrezno strokovno izpopolnjevanje bi lahko pomembno pripomogli $\mathrm{k}$ zboljšanju izobraževanja učiteljev. Potreben bi bil podroben pregled strokovnih kvalifikacij za izobraževalce učiteljev, posebni ukrepi za uvajanje $\mathrm{v}$ njihovo poklicno kulturo in priprava programov za njihov razvoj.

Ali se je $\mathrm{v}$ zadnjih desetih letih kaj bistveneg spremenilo? Še vedno se nam zastavljajo vprašanja, od kod izobraževalci prihajajo, kako poteka njihov profesionalni razvoj, katere kompetence potrebujejo in kako jih pridobijo, ali se med seboj povezujejo, izmenjujejo izkušnje. Odgovorov na ta vprašanja v slovenskem prostoru nimamo. Zavod RS za šolstvo, Center za poklicno izobraževanje in Šola za ravnatelje s svojimi dejavnostmi pokrivajo tudi izobraževanje in usposabljanje strokovnih delavcev na področju vzgoje in izobraževanja. Vsaka od teh inštitucij na svoj način usposablja izobraževalce, postavlja kriterije za njihov izbor, razmišlja o njihovem profesionalnem razvoju, a se pri tem ne povezuje $\mathrm{z}$ drugimi, čeprav sta partnerski odnos in sodelovanje eni najpogostejših besed $\mathrm{v}$ sodobnem strokovnem besednjaku.

Andragoški center Slovenije s svojimi pobudami občasno poveže različne akterje na področju zobraževanja odraslih. V izhodiščih za razpravo na okrogli mizi, ki je potekala na ACS, je bilo zapisano, da je izobraževanje odraslih področje, kjer se srečuje veliko različnih disciplin in strokovnjakov, ki se med seboj pomembno razlikujejo, ob tem pa jih kot izobraževalce odraslih povezujejo skupni cilji. Pri doseganju teh ciljev težijo $\mathrm{k}$ skupni metodologiji dela, iskanju skupnih orodij jezika, za kar morajo razviti podobne kompetence, spretnosti in pridobiti podobno znanje. Klemenčič (2009: 120) v zaključnih ugotovitvah navaja: »/.../ da se je pojavila tudi potreba po program $/ . . /$ da se je pobre

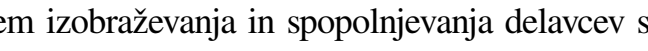
področja vzgoje in izobraževanja «.

To je razmislek, ki bi ga bilo treba umestiti v siršo razpravo na nacionalni ravni in povezati vse akterje, ki delajo na področju učenja odraslih - tudi tiste, ki delajo na področju nadaljnjega izobraževanja in usposabljanja strokovnih delavcev vzgoje in izobraževanja. Diskusija vabljenih strokovnjakov z različnih področij, ki je marca 2010 potekala $\mathrm{v}$ okviru tematskih okroglih miz ACS in je nosila pomenljiv naslov »Kako v Sloveniji skrbimo za usposobljenost izobraževalcev odraslih«, je bila prvi korak v pravo smer. Poleg drugih strokovnjakov so bili navzoči tudi predstavniki ministrstva za šolstvo in šport s področja zobraževanja odraslih in sogovorniki s področja nadaljnjega izobraževanja in usposabljanja učiteljev. Nujna bi bila vzpostavitev dialoga med obema sektorjema v okviru ministrstva, kar bi posledično vplivalo tudi na sodelovanje javnih zavodov, ki so pristojni za posamezna področja. Druga pot je samoiniciativno organiziranje in povezovanje strokovnjakov v mrežo, ki bi pokrila zainteresirane s področja izobraževanja različnih ciljnih skupin odraslih. Skupna tema vseh je zagotovo poklicna identiteta, kompetence in profesionalni razvoj izobraževalcev. S roglih mizah in mrežah strokovnjakov, ki imajo skupno poslanstvo, bi zagotovo obrodilo sadove in odgovorilo na vprašanja, ki si jih zdaj zastavljamo vsak na svojem bregu.

\section{LITERATURA}

Brocher, T. (1972). Skupinska dinamika in izobraževanje odraslih. Ljubljana: Državna založba

Bulskool, B. J. Broek, S. D., van Lakerveld, J. Zafiris, G. K. ( 2010). Key competences for Adult Learning Professionals. Final Report, Zoetem

Cencič, M. (2010). Izobraževanje izobraževalces. CRP 2008-2010. Model evalvacije kakovosti izvajalcev programov usposabljanj strokovnih delavcev. Univerza na Primorskem, Pedagoška fakulteta.

CLIMATE project, http://www.socialsciences.leiden. edu/plato/climate.

Day, Christopher. (1999) Developing Teachers, The Challenges of Lifelong Learning. London: Falmer Press.

Hargreaves Andy, Fullan Michael (2000): »Mentoring in the New Millennium«. Theory into Practice. 39 (1): 50-56.

Kessels. J. W. M. (1996). Het corporate curriculum. Oratie 26 februari 1996. Leiden: Universite Leiden.

Klemenčǐč, S. Možina, T. ( 2009). Kompetenčni pristop $k$ izobraževanju andragoških delavcev (elektronski vir). Ljubljana: Andragoški center RS Slovenije.

Knowles, M. S. (1990). The Adult Learner: a Neglected Species. 4th edition, Houston: Gulf Publishing Company, Book Division

Korthagen, F. (2009). »Praksa, teorija in osebnost v

$$
\text { 40: 4-14 }
$$
arentičc-Požarnik, B. (2000). »Profesionalizacija

uspešne prenove«. Vzgoja in izobraževanje, 31 (4) $4-11$

Milović, S. (ur.), (2010). Stručno usavršavanje i profesionalni razvoj, Agencija za odgoj i obrazovanje. Zagreb.

Mršnik, S. et al. (2005): Evalvacija projekta Izo. adivo za interno uporabo

Ninisto, K. (1996). »Change Agent Teacher - Becoming a Teacher in a Developing Organisation «. V Helsinki: University of Helsinki, 145-150.

Sachs, J. (2003). The Activist Teaching Profession. Open University Press.

Smith, K. (2003). »So, What About Professional Developart of Teacher Educators? « European Joumal of Teacher Education, 26 (2): 201-216.

Swennen, A., van der Klink, M. (ur.). (2010). Becoming a Teacher Educator, Theory and practice for Teacher Educators. Springer.

aiil, P. (1996). Learning as a way of being. San Francisco: Jossey-Bass Publishers.

Van Lakerveld, J. (2006): »Ustvarjanje znanja -

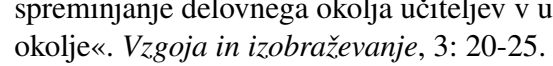

Van Lakerveld J. (2005). Het Corporate Curriculum, Onderzoek naar werk-leeromstandigheden in init Twente, Enschede.

Van Lakerveld, J., Engels, N. et al. (2010). CLIMATE: Contextual Learning In

Zelena knjiga o izobraževanju učiteljev v Evropi. kakovost v vzgoii, izobraževanju in usposabljanju Ljubljana: Ministrstvo za šolstvo, znanost in šport.

Zgaga, P. (2010). Education and Society - The Role Tenca ministrov za izobržnevaje Sveta Evrope.

Žrkovič Adleš̌č B. (2006) « Multiplikatori:

prevzemanje odgovornosti za lasten profesional razvoj 20 .

Žarkovič Adlešǐč, B. et al. (2004). Strokovna in osebnostna rast. Interni projekt Zavoda RS za šolstvo. 